\title{
Structural Geology Analysis In A Disaster-Prone Of Slope Failure, Merangin Village, Kuok District, Kampar Regency, Riau Province
}

\author{
Yuniarti Yuskar ${ }^{1}$, Dewandra Bagus Eka Putra ${ }^{1}$, Adi Suryadi ${ }^{1}$, Tiggi Choanji ${ }^{1}$, Catur \\ Cahyaningsih $^{1}$ \\ ${ }^{1}$ Department of Geological Engineering, Universitas Islam Riau, Jl. Kaharuddin Nasution No 113 Pekanbaru, 28284, Indonesia.
}

* Corresponding author : yuniarti yuskar@eng.uir.ac.id

Tel.: .: +62-821-6935-4941

Received: Sept 02, 2017. Revised : 1 Nov 2017, Accepted: Nov 15, 2017, Published: 1 Dec 2017

DOI : 10.24273/jgeet.2017.2.4.691

\begin{abstract}
The geological disaster of landslide has occurred in Merangin Village, Kuok Subdistrict, Kampar Regency, Riau Province which located exactly in the national road of Riau - West Sumatra at Km 91. Based on the occurrence of landslide, this research was conducted to study geological structure and engineering geology to determine the main factors causing landslides. Based on measurement of the structural geology found on research area, there were fractures, faults and fold rocks which having trend of stress N $2380 \mathrm{E}$, plunge 60, trending NE-SW direction. Several faults that found was normal faults directing N $2000 \mathrm{E}$ with dip 200 trending from northeast-southwest and reverse fault impinging N $550 \mathrm{E}$ with dip 550, pitch 200 trending to the northeast. Fold structures showing azimuth N 2010 E trending southeast-northwest. From geological engineering analysis, the results of scan line at 6 sites that have RQD value ranges 9.4\%- 78.7 \%with discontinuity spacing $4-20 \mathrm{~cm}$. So, It can be concluded that the formed structure was influenced by the extensive northeast-southwest tectonic phase, then continued through north-south tectonic phase, and ended by a tectonic period with directing from northeast-southwest. Rock Mass Rating classification showing value $62-76$, Which also resulted that rocks in the study area have weathered on the outside but still in good condition (good rock). However, This condition of structure has caused the formation rocks producing weak zone that became one cause of the occurrence of landslides.
\end{abstract}

Keywords: Landslide, Geological Structure, RQD, Rock Mass Rating.

\section{Introduction}

The landslide was one of the geological disaster (McKean et al, 2004; Booth et al, 2009; \& Tarolli et al, 2012),. It has several intrinsic parameters which are considered are; slope geometry, slope material (rock or soil type), structural discontinuities, landuse and landcover and groundwater (Raghuvanshi et al , 2014), and for studying it need avalaibility of database files (Wirtz et al, 2012).

This landslide often occur in Pekanbaru - West Sumatra roads, especially at km 91 (Fig 1.). The impact of the avalanche which directly hit the road makes difficult for vehicles to mobilize and congestion up to several kilometres. This case certainly very harmful to its users. The purpose of this research was to determine the effect of landslide disaster based on geology analysis that occurred in the area.

\section{Geology Regional}

Research area was part of Central Sumatra Basin, Consist of basement (Bohorok Formation), greywacke, conglomeratic, and metasediment rock.
The Pre-Tersier framew ork of Sumatra consists of a mosaic of continental and oceanic microplate accreted in the Late Triassic when Mergui, Malacca and East Malaya Microplate were joined together to form Sunda Land. Further accretion involving the west coast Woyla Terrain followed in the late Mesozoic (Pullonggono, 1984).

Cenozoic structural development involved three geometrically and kinematically distinct episode of faulting and folding. Three include: 1) Eo-Oligosen rifting (F1) along old basement breaks of N - NNE strike and reactivation of WNW-trending regional basement arches; 2) Early Miocene (F2) crustal sagging, regional dextral wrenching, local counterclockwise kinking (150-250) of older N-S faults and development of N $0-200 \mathrm{E}$ striking transtensional fracture zone; and 3) Middle Miocene to Recent (F3) WSW directed thrusting and reverse faulting along older wrench faults of NNW-strike, SSW-verging monoclinal flexuring across older NW - WNW trending basement breaks, and transtensional rifting alon element of N-NNE strike (Heidrick and Aulia, 1993). Fracture frequency important to distinguish high/low-frequency fracture zone and 
find damage zone (Putra and Choanji, 2016). The majority of fault-related fracture is shear fracture arc basin, Barisan Vulcanic Arc, and Sumatra Fault conjugate to the fault (Saputra and Sapi ie, 2005).

\section{Methodology}

This research conducted by doing measurement on geological data, such as Fractures, faults and folds. Folds and Faults are directly measured at sites to gain the stress data by using stereography methods.

Meanwhile, the fracture data, was collected by performing scan line method. Also there are several measurements to identified fracture, which are: type of shear fractures or tension fractures, strike and dip, mineral filled, distance, trace length. So based on the data, furthermore, stereography and rose diagram analyzes were performed to determine the direction of stress, type of faults, and folds, angle and plunge direction.
Rock mass rating system also used to classify rock mass based on Uniaxial Comprehensive Strength parameter, Rock Quality Designation (RQD), Space of Discontinuity, Discontinuity Condition, and Groundwater Condition by using geological hammer that used to determine rock strength in the field and being converted into UCS value using Index Classification of Rock Material by Hoek and Brown 1980. Indirect RQD method was used in this method because of the absence of core log. RQD value calculated using Palmstrom (1982) formula:

$$
\mathrm{RQD}=115-3,3 \mathrm{~J} \mathrm{v}
$$

Where :

$\mathrm{Jv}=$ Total Fractures per m3.

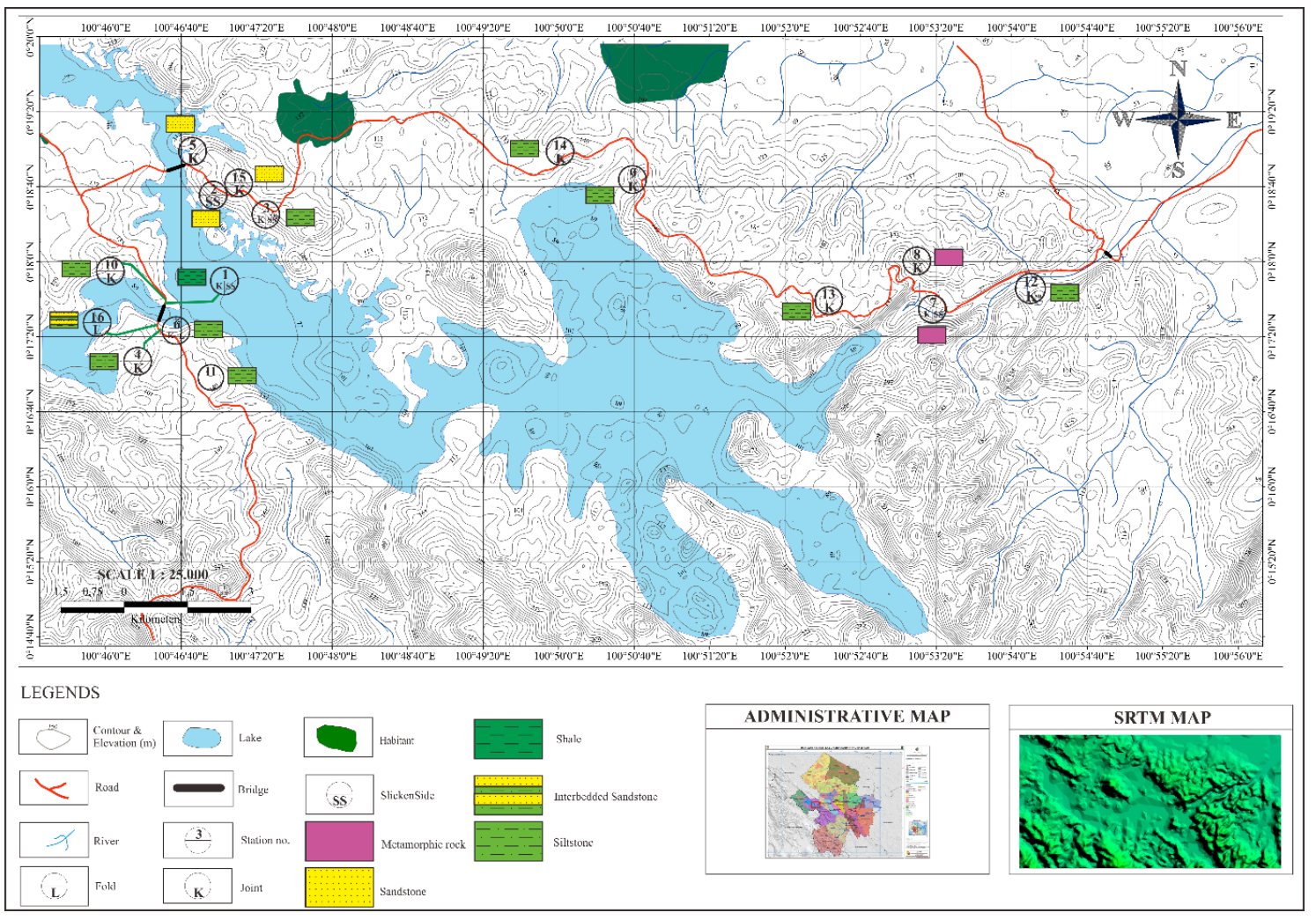

Fig 1. Research location map.

Table 1. Stress analysis result of fault

\begin{tabular}{ccccccc}
\hline Fault plane & $\begin{array}{c}\text { Strike } \\
\text { /dip }\end{array}$ & Pitch direction & $\boldsymbol{\sigma} 1$ & $\boldsymbol{\sigma} 2$ & $\boldsymbol{\sigma} 3$ & Stress direction \\
\hline $\mathrm{ST} 1$ & $\mathrm{~N} 140^{\circ} \mathrm{E} / 45^{\circ}$ & $\mathrm{N} 343^{\circ} \mathrm{E}$ & $2^{\circ}, \mathrm{N} 1^{\circ} \mathrm{E}$ & $37^{\circ}, \mathrm{N} 270^{\circ} \mathrm{E}$ & $52^{\circ}, \mathrm{N} 95^{\circ} \mathrm{E}$ & North-South \\
$\mathrm{ST} 2$ & $\mathrm{~N} 205^{\circ} \mathrm{E} / 65^{\circ}$ & $\mathrm{N} 212^{\circ} \mathrm{E}$ & $27^{\circ}, \mathrm{N} 179^{\circ} \mathrm{E}$ & $60^{\circ}, \mathrm{N} 335^{\circ} \mathrm{E}$ & $10^{\circ}, \mathrm{N} 83^{\circ} \mathrm{E}$ & North-South \\
$\mathrm{ST} 3$ & $\mathrm{~N} 20^{\circ} \mathrm{E} / 35^{\circ}$ & $\mathrm{N} 48^{\circ} \mathrm{E}$ & $37^{\circ}, \mathrm{N} 34^{\circ} \mathrm{E}$ & $21^{\circ}, \mathrm{N} 142^{\circ} \mathrm{E}$ & $43^{\circ}, \mathrm{N} 254^{\circ} \mathrm{E}$ & Northeast-Southwest \\
$\mathrm{ST} 7$ & $\mathrm{~N} 200^{\circ} \mathrm{E} / 70^{\circ}$ & $\mathrm{N} 241^{\circ} \mathrm{E}$ & $68^{\circ}, \mathrm{N} 164^{\circ} \mathrm{E}$ & $18^{\circ}, \mathrm{N} 12^{\circ} \mathrm{E}$ & $10^{\circ}, \mathrm{N} 278^{\circ} \mathrm{E}$ & NNW-SSE \\
\hline
\end{tabular}




\section{Result}

\subsection{Fold Analysis}

Fold structures that had been found in the study area were classified into type of recumbent fold and symmetrical fold of interbedded sandstoneclaystone (Fig. 2). The stress consists of $\delta 1 \mathrm{~N} 222^{\circ} \mathrm{E}$ with $30^{\circ}$ plunges, $\delta 2 \mathrm{~N} 322^{\circ} \mathrm{E}$ with plunge $17^{\circ}$ and $\delta 3$ $\mathrm{N} 76^{\circ} \mathrm{E}$ with plunge $55^{\circ}$ (Fig. 2).

The lithology of this folds was consist of sandstone what has grey colour, non-calcareous, fracture filled by quartz veins and metasediment of claystone. Low metamorphism process had been shown in the outcrop by the presence of foliation, so this outcrop was called meta-sedimentary rock. So based on the analysis, this folded structure interpreted caused by a compression on northeastsouthwest direction.

\subsection{Fault Analysis}

There are 4 (four) fault structures that had been found in the study area (Table 1). Firstly, Normal fault system had found in Station 7.
Fault structure happens on Lithology pebble claystone, it was indicated by weak zone and slickenside. Slickenside shows the fault plane in $\mathrm{N} 290^{\circ} \mathrm{E} / 70^{\circ}$ with $70^{\circ}$ pitch and southwest movement direction. Analysis of stereographic projection showing the stress direction of normal fault is in northwest-southeast (Fig. 3). The stress value of the fault gives $\delta 1$ in $N 52^{\circ} \mathrm{E}$ direction with $68^{\circ}$ plunges, $\delta 2$ in $\mathrm{N} 207^{\circ} \mathrm{E}$ direction with $20^{\circ}$ plunges and $\delta 3$ in $\mathrm{N} 299^{\circ} \mathrm{E}$ with $10^{\circ}$ plunges.

Station 2 also showing the same analysis result as station 7 .

The other fault system was a reverse fault in station 1, having length size $55 \mathrm{~m}$ and $22 \mathrm{~m}$ high, which consist of greywacke, low metamorphic sandstone, phyllite, conglomerate, quartzite and mylonite. From the measurement, it has indicated that this fault has azimuth value of $140^{\circ} \mathrm{E} / 45^{\circ}$, pitch $30^{\circ}$ and trend $\mathrm{N} 330^{\circ}$ SE directing northwest. Therefore, the stress resulting $\delta 11^{\circ}$ trending and classified as right - reverse fault in ST 1 , its called Gulamo Right - Reverse Fault. (Fig. 4).
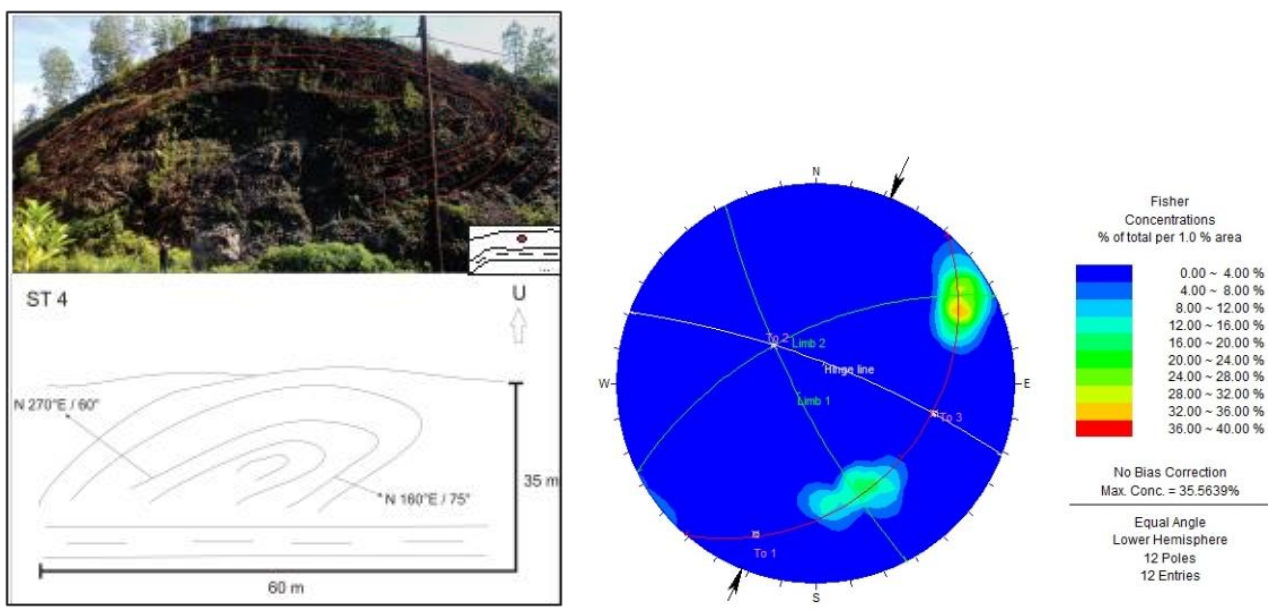

Fig 2. Fold structure ST 6 at research location (left) and stereographic analysis of fold structure (right)
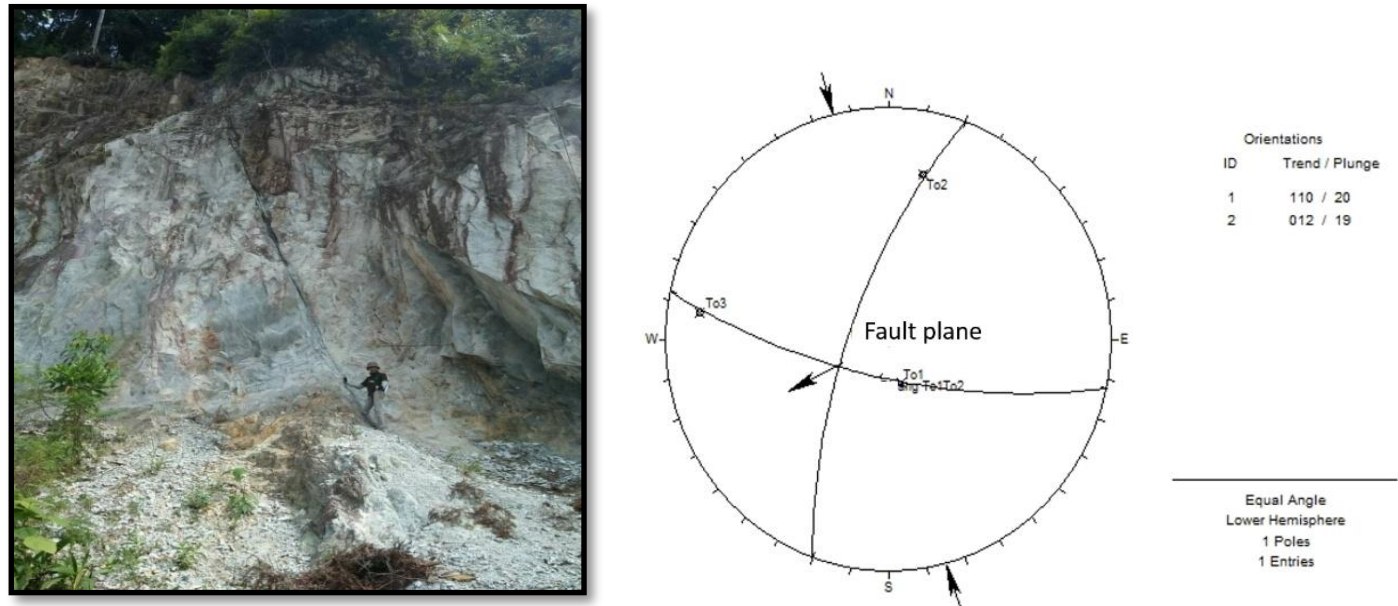

Fig 3. Fault structure in ST 7 at research location classified as normal fault (Left) and Stereonet analysis of normal fault structure (Right) 


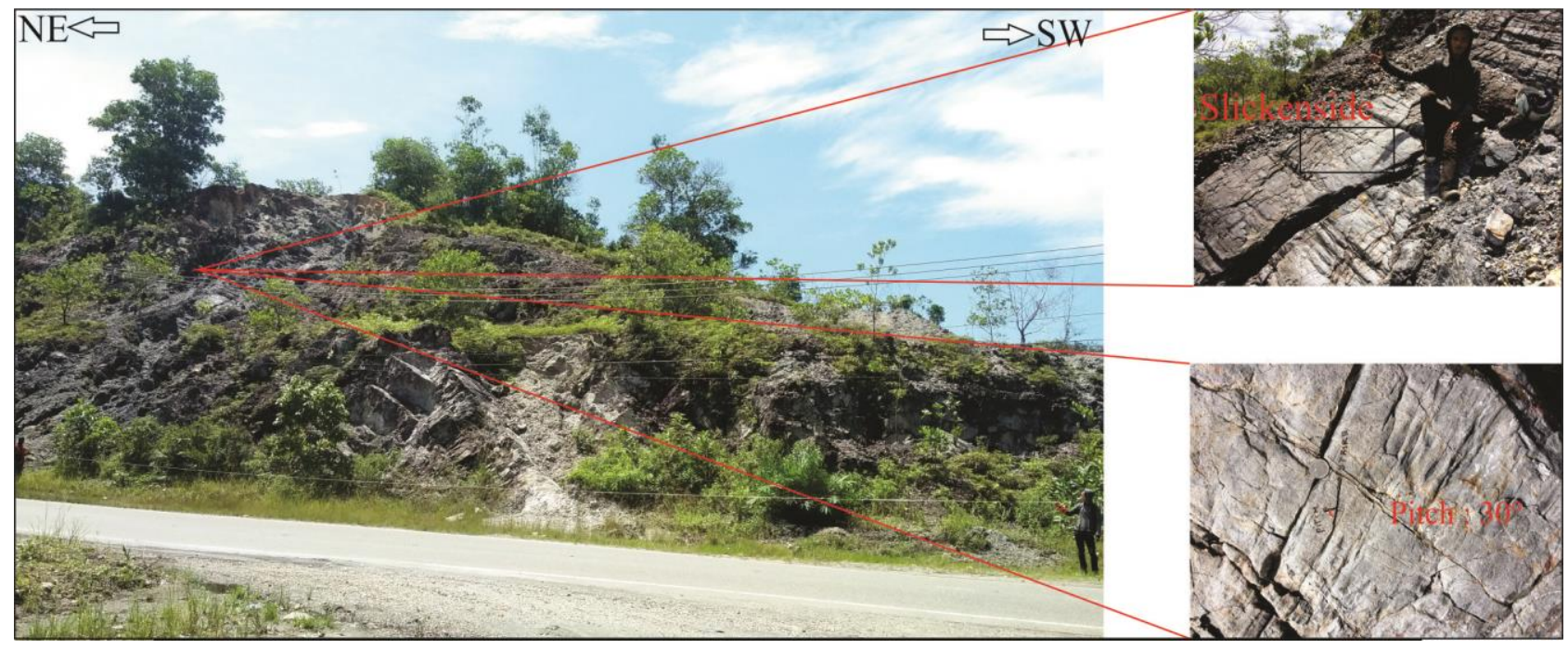

Fig 4. Reverse fault in ST 1 on research location.
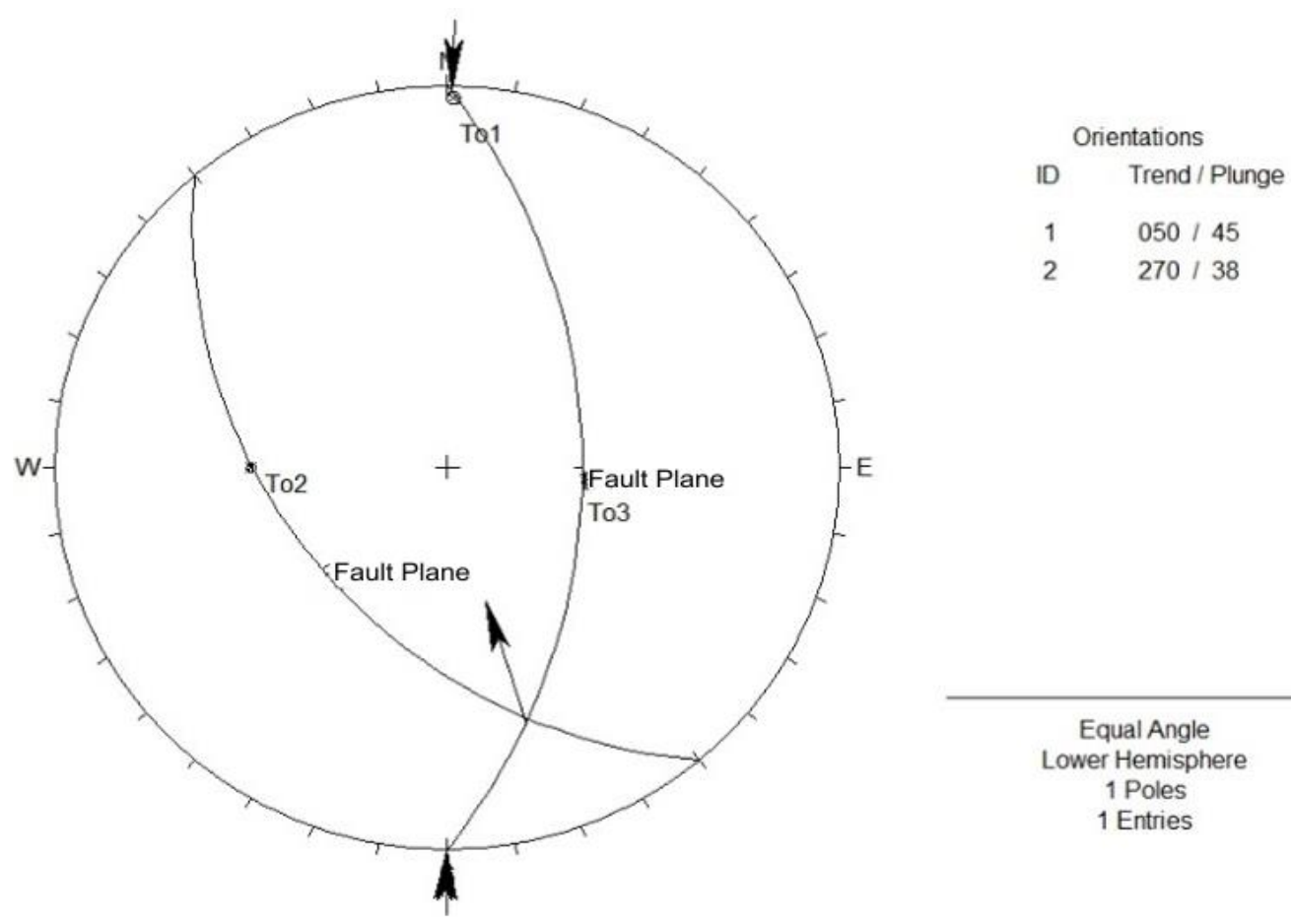

Fig 5. Stereographic analysis of reverse fault at research location.

\subsection{Fractures Structure Analysis}

There are 9 (nine) sites of fractures structure (location 1, 3, 8. 9. 10. 12.13. 14 and 15) shows a similar stress direction in northeast-southwest (Fig 6.). The stress in Station 1 consists of $\delta 1$ in $N 238^{\circ} \mathrm{E}$ direction with $6^{\circ}$ plunges, $\delta 2$ in $\mathrm{N} 344^{\circ} \mathrm{E}$ direction with $43^{\circ}$ plunges and $\delta 3$ in $N 142^{\circ} \mathrm{E}$ with $6^{\circ}$ plunges. The stress in Station 5 consists of $\delta 1$ in $N 3^{\circ} \mathrm{E}$ direction with $3^{\circ}$ plunges, $\delta 2$ in $N 184^{\circ} \mathrm{E}$ direction with $4^{\circ}$ plunges and $\delta 3$ in $N 193^{\circ} \mathrm{E}$ with $3^{\circ}$ plunges. The stress in Station 12 consist of $\delta 1$ in $N 30^{\circ} \mathrm{E}$ direction with $19^{\circ}$ plunges, $\delta 2$ in $\mathrm{N} 263^{\circ} \mathrm{E}$ direction with $59^{\circ}$ plunges and $\delta 3$ in $\mathrm{N} 127^{\circ} \mathrm{E}$ with $22^{\circ}$ plunge.

The Geological structure such as fold, fault and fracture are formed due to extensional stress at rifting phases and then strike/ slip system continue. And the last, compressional stress are worked in this area and still active until Recent. 

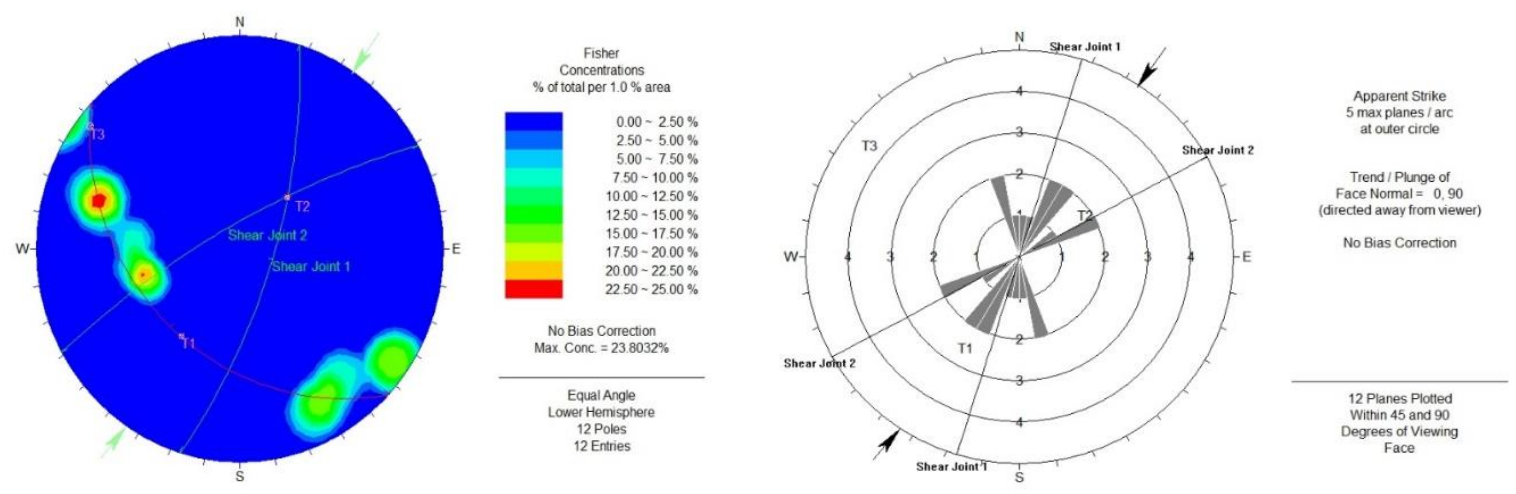

(a)
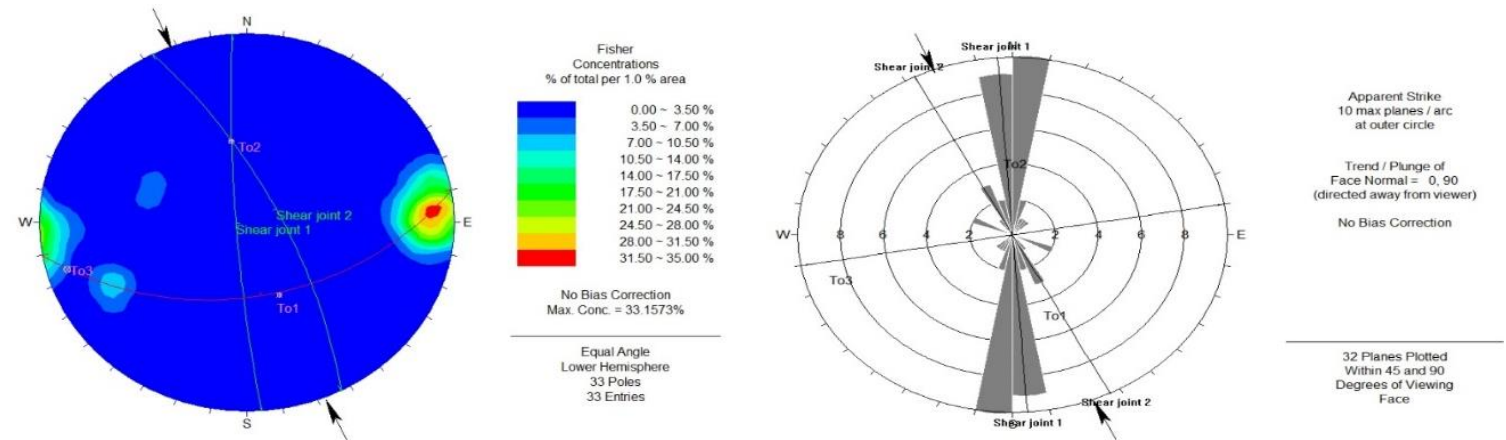

(b)
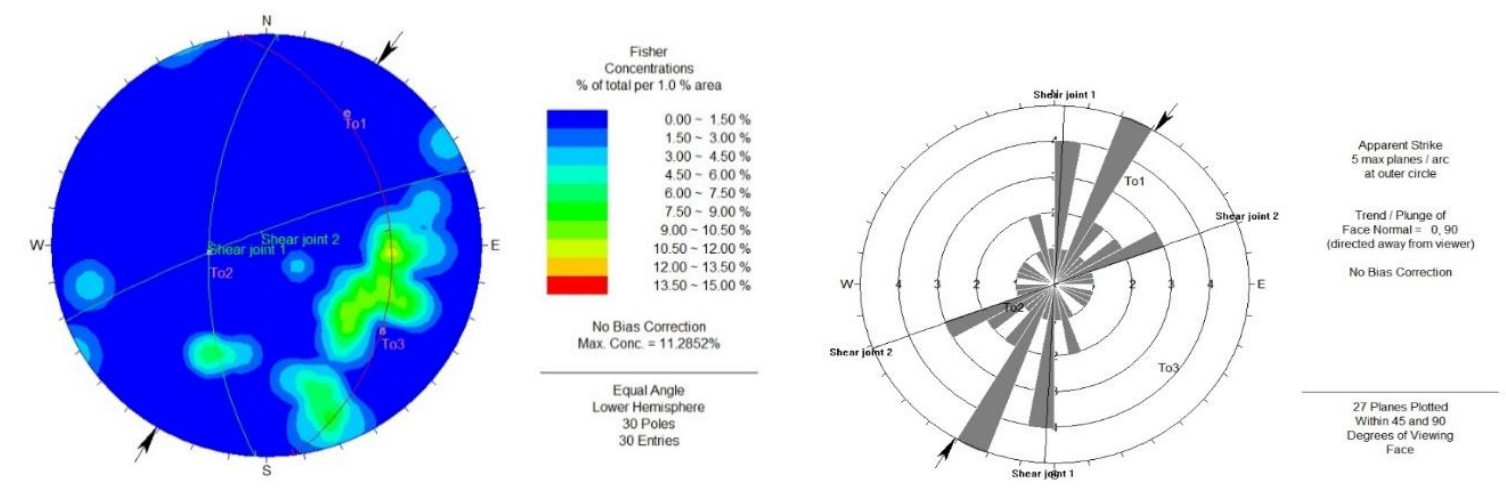

(c)

Fig. 6. Fracture structure analysis in at location (a) ST 1, (b) ST 8, and (C) ST 12.

\subsection{Geological Engineering Analysis}

Based on 6 scan lines data in the research area, The UCS (Uniaxial Compressive Strength) value of slope in the study are 25$100 \mathrm{Mpa}$, from the hillside 2-6, the percentage of RQD value was in the range 32 - 42. Table 2 shows the overall calculation of RMR parameters. From the table, RMR value in each section of scanline ranging from 61 to 80 and the slope can be classified as a Class II Rock (Good Rock).
Table 2. Calculation of RMR value of each scan line

\begin{tabular}{cc}
\hline Hillside & RMR Value \\
\hline 2 & 37 \\
3 & 58.5 \\
4 & 14 \\
5 & 37 \\
6 & 40.75 \\
\hline
\end{tabular}

\section{Discussion}

The analysis result of Fracture, Fault, and Fold structures showed that the structure was formed by tectonic in phases F1, F2, and F3 
(Heidrick and Aulia, 1993). In the research area, showed northeast-southwest direction formed by the compression force in Phase F3 in the Central Sumatra Basin. The fault structure found in metasedimentary rocks at Permo-Carbon is a normal fault formed by extensional forces at Eocene-Oligocene F1 Phase which subsequently reactivated by phase F3. Continued by strike-slip fault structure that formed at phase F2 which reactivates the fault. The compressional stress also created the formation of folds. The research area was showing stress value that still active until today where located near weak zone, indicated by the discovery of the destruction zone and mylonite zone. The active movement of the tectonics is become one indicator for landslides in rocks with intensive weathering, whereas in rock that relatively hard and compact is still showing good rock category. So the conclusion was still in probability due to rocks that have been weathered and affected by the active movement of tectonics can be one cause of landslides in the research area.

\section{Conclusion}

The research area was an active structural zone consisting of fracture, fault and folds trending northeast-southwest. The structures formed are the result of tectonic phases that work in the research area. it is interpreted that tectonic was trending northeastsouthwest and North-South. Based on the RMR analysis, research area showed that the rocks that have weathered on the outside but still in good condition (good rock).

\section{References}

Booth AM, Roering J, Perron JT. Automated Landslide Mapping Using Spectral Analysis and High- resolution Topographic Data: Puget Sound lowlands, Washington, and Portland Hills, Oregon. Geomorphology 2009; 109:132147.

Clarke drr., P3G .1982. Peta Geologi Lembar Pakanbaru, Sumatera. Pusat Penelitian dan Pengembangan Geologi, Bandung.

Eubank, R.T., \& Makki, A. C., 1981, Structural Geology of The Central Sumatra Back-arc Basin, Proceeding IPA, $10^{\text {th }}$ Annual Convention, p 285 $-317$.

Heidrick, T.L., dan Aulia, K., 1993, A Structural and Tectonic Model of The Coastal Plain Block, Central Sumatra Basin, Indonesia, Proceeding IPA, $22^{\text {th }}$ Annual Convention, Jakarta.

McKean J, Roering J .2004. Objective Landslide Detection and Surface Morphology Mapping Using High-resolution Airborne Laser
Altimetry. Geomorphology;57:331-351. Papagiannaki, K., Lagouvardos, K., \& Kotroni, V .2013. A database of high-impact weather events in Greece: a descriptive impact analysis for the period 2001e 2011. Natural Hazards and Earth System Science, 13, 727e736. http://dx.doi.org/ 10.5194/nhess-13-727-2013.

Raghuvanshi, T.K., Ibrahim, J., Ayalew, D .2014. Slope stability susceptibility evaluation parameter (SSEP) rating scheme - an approach for landslide hazard zonation. J. Afr. Earth Sci. 99, 595- 612.

Putra, D.B.E., Choanji, T., 2016. Preliminary Analysis of Slope Stability in Kuok and Surrounding Areas. J. Geosci. Eng. Environ. Technol. 1, 41-44.

Pulonggono, A and Cameron, N. R.., 1984, Sumatran Microplate, their characteristic and their role in Evolution of Central Sumatra Basins: Proceedings Indonesian Petroleum Association, $13^{\text {th }}$ Annual Convention, p. $121-143$.

Saputra, H.N and Sapiie, B., 2005, Analogue Study of Basement Fractured Reservoirs in Kotopanjang Area, Central Sumatra: Proceedings Indonesian Petroleum Association, $33^{\text {th }}$ Annual Convention.

Tarolli P, Sofia G, Dalla Fontana G .2012. Geomorphic Features Extraction from Highresolution Topography: Landslide Crowns and Bank Erosion. Nat Hazards 2012;61:65-83.

Wirtz, A., Kron, W., Löw, P., \& Steuer, M .2012. The need for data: natural disasters and the challenges of database management. Natural Hazards, le23. http:// dx.doi.org/10.1007/s11069-012-0312-4. 